\title{
Marko Vidmar
}

E-mail: mvidmar92@gmail.com

\section{Marino Žagar}

E-mail: zaxy45@gmail.com

University of Rijeka, Faculty of Maritime Studies, Studentska 2, 51000 Rijeka, Croatia

Mile Perić

E-mail: mile.peric@ak-rijeka.hr

Automobile Club, Dolac 11, 51000 Rijeka, Croatia

\section{Projection of the Electronic Toll Collection System in the Republic of Croatia}

\begin{abstract}
This paper deals with the topic of a modern electronic toll collection system that will be applied in the Republic of Croatia from the year 2022 onwards. The paper primarily analyses the existing toll collection systems in Croatia, as well as in the European Union. Modern electronic toll collection systems were analysed with an emphasis on the ANPR (Automatic Number Plate Recognition) system, because ANPR technology will be used in Croatia after the restructuring of road traffic occurs. ANPR is not a new technology, however in the last twenty years it has found its wider application. This happened mostly thanks to local and global infrastructural development and technological improvements therefore in turn infrastructure required for the operation of this system became cheaper. By applying the ETC and ANPR, Croatia will have a system in line with European directives and practices which are being applied in other European countries. The system will in turn significantly raise the quality of road traffic in Croatia and reduce its costs.
\end{abstract}

Key words: electronic toll collection, road traffic restructuring, ANPR

\section{Introduction}

In the present day, Croatia has a premium quality motorway network which spans through more than 1,300 kilometres of motorways. 96\% of Croatian motorways have a low and medium low traffic accident rate. According to the World Economic Forum report from 2018, the Croatian road infrastructure is ranked 13th out of a total of 137 countries included in the study. Motorways directly contribute to traffic safety as well as being an important feature of economic development. In Croatia, where more than 
$85 \%$ of tourists are accounted for by road traffic, the quality in addition to the amount of motorways remain an important factor for the development of tourism [1].

Motorway development is a long-term project. In order for Croatia to enable the project, it has often loaned out at a disadvantage throughout history. Consequently, this burdened the road sector with a large debt of five billion euros, which at the end of 2017 represented almost $13 \%$ of the public debt of the Republic of Croatia. In order to reduce debt and to increase business efficiency, in 2017 the Republic of Croatia has launched a reform of the road sector for the period from 2017 to 2030. By refinancing about $60 \%$ of the total dues and annual savings, financial sustainability has been achieved. The debt will be paid off almost in full by the year 2033 [1].

The existing toll collection system has not been changed since the construction of motorways in Croatia until the year 2006. At that time the ETC was introduced, the electronic toll collection system based on the use of ETC devices. The ETC device has enabled a higher flow rate of vehicles on motorways. The infrastructure has been adapted to it in terms of introducing special lanes exclusively for users of ETC technology.

Although the introduction of this technology represented a revolution in toll collection in Croatia, during the summer season, when the influx of vehicles is increased due to tourists, toll stations regularly get crowded. Because of this trend, the Ministry of the Sea, Transport and Infrastructure of the Republic of Croatia has launched an initiative to restructure road traffic by the means of a new, modern system of electronic toll collection.

\section{Existing toll collection systems}

In order to be able to talk about modern toll collection systems and notice their advantages, it is necessary to analyse the existing toll collection system first. For this purpose, the existing toll collection systems in Croatia but also in Europe will be analysed, in order to ultimately determine how much the modern electronic toll collection system in Croatia, planned for use from 2022, will be in line with modern toll collection systems in Europe.

\subsection{Existing toll collection systems in Croatia}

Motorways in Croatia are managed by four companies: Hrvatske autoceste (HAC), Autocesta Rijeka - Zagreb (ARZ), Autocesta Zagreb - Macelj (AZM; private concessionaire), Bina-Istra (private concessionaire). The existing electronic toll collection system is a "Stop \& Go" type of system. The challenges of the existing system relate to the technical difficulties which stem from the out-dated system and the operational costs of billing, where a great number of resources are required - human, financial as well as hardware. One of the biggest difficulties for such a toll collection 
system is the fact that it does not have a high flow rate, which is why large traffic jams are regularly created at toll booths on Croatian motorways in the summer months [1].

The current toll collection system takes place at toll booths or stations, and can be paid in cash in HRK or (for non-residents) in Euros, cards (Diners, MasterCard, Maestro, Visa, INA, MOLGROUP) or via ETC devices ${ }^{1}$. At this time, this is the only form of electronic toll collection in Croatia.

In the Republic of Croatia, open and closed toll systems are applied on motorways. An open toll collection system refers to a system in which the toll booth at the same time functions as a place of entry as well as a place of exit for toll collection.

On motorways with multiple entrances and exits, a closed toll system is applied, in which the motorway user is registered in the system at the entrance toll station by taking a toll card or by enabling the reading of the ETC device. At the exit toll station, users hand over the toll card or enable the reading of the ETC device and, according to the data, pay the toll. [2] ETC devices are used for contactless electronic toll collection without the mediation of the cashier. According to the instructions, the ETC device must be located on the tinted part of the vehicle's windscreen and be read by the antenna on the toll lane. [3] When a vehicle equipped with an ETC device approaches an output hybrid strip equipped with an ETC system, the antenna detects the ETC device, reads the stored input station data and displays the vehicle category, toll amount, means of payment and remaining account balance. The road barrier is raised and the vehicle can leave the exit lane. [4] Users of all vehicle groups can use the ETC device.

\subsubsection{Categorization of toll vehicles}

According to Article 2, Title II of the Toll Ordinance (Narodne novine, 130/13.), which was put into effect on November 5, 2013, vehicles are allocated for toll collection purposes into the following groups [5]:

- IA Motorcycles, motor tricycles and quadricycles,

- I Motor vehicles with two axles, height up to $1.90 \mathrm{~m}$,

- II:

a) Motor vehicles with two axles higher than $1.90 \mathrm{~m}$, with a maximum permissible mass not exceeding $3500 \mathrm{~kg}$,

b) Motor vehicles with two axles, less than $1.90 \mathrm{~m}$ high, towing a trailer, regardless of the number of axles and the height of the trailer.

- III:

a) Motor vehicles with two or three axles, maximum permissible mass over 3500 $\mathrm{kg}$,

$\overline{\text { Electronic toll collection device }}$ 
b) Motor vehicles with two axles, maximum permissible mass exceeding 3500 $\mathrm{kg}$, towing a trailer with one axle,

c) Motor vehicles referred to in II a) towing a trailer, regardless of the number of axles of the trailer.

- IV:

a) Motor vehicles with four or more axles, maximum permissible mass exceeding $3500 \mathrm{~kg}$,

b) Motor vehicles with two axles, maximum permissible mass over $3500 \mathrm{~kg}$, towing a trailer with two or more axles,

c) Motor vehicles with three axles, maximum permissible mass over $3500 \mathrm{~kg}$, towing a trailer, regardless of the number of axles of the trailer.

In the Republic of Croatia, tolls are charged in proportion to the length of the section used and according to the belonging group of vehicles. Although toll collection has been significantly accelerated with the introduction of payment via ETC devices, congestion is still being created on motorways. Foreigners, who generally do not have an ETC device, have to spend more and more time standing to pay for the use of the highway, so in order to improve things, it is necessary to introduce another, better, faster and more efficient way of paying tolls in Croatia.

\subsection{Existing electronic toll collection systems in Europe}

Since 1971, the European Union has been committed to the establishment of a pricing policy for the use of infrastructure that would be fair and accepted by all member states. Although European countries use more technological variants and charging models (according to the distance traveled and according to the time limit). DSRC ${ }^{2}$, i.e. the use of ETC devices, is currently the most widespread and accepted technology. The billing system itself is done in several different ways [1]:

1. according to the method of calculation: according to the time limit; according to distance; there is no charge,

2. according to the flow of vehicles: free flow; barrier,

3. according to technology: DSRC; DSRC-ALPR ${ }^{3}$; SNSS $^{4}$; vignette / e-vignette supported by ALPR.

\footnotetext{
2 Dedicated Short-Range Communication

Automatic Licence Plate Recognition; also ANPR - Automatic Number Plate Recognition

Global Navigation Satellite System
} 
In Figure 1 it is shown how the toll is paid for in Europe for light vehicles category.

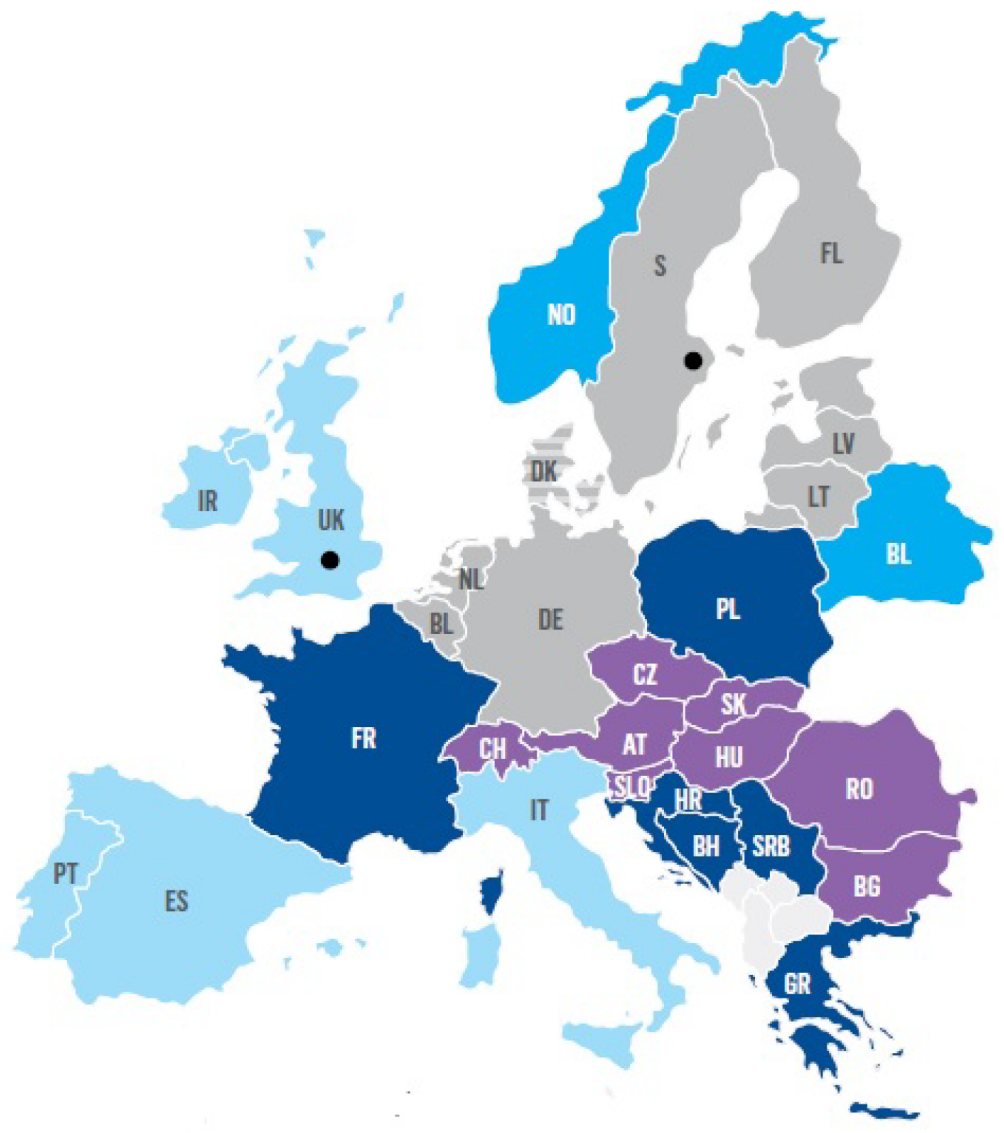

\section{According to distance; road barriers, DSRC}

According to distance; free flow; DSRC

According to distance; free flow; road barriers, DSRC

According to the time limit (vignette); free flow; vignette / e-vignette supported by ALPR

There is no charge

Charging for special facilities in Denmark

- $\quad$ ALPR (large cities)

Figure 1 - Toll payment in Europe for the light vehicles category [1] 
In Figure 2 it is shown how the toll is paid for in Europe for the heavy vehicles category.

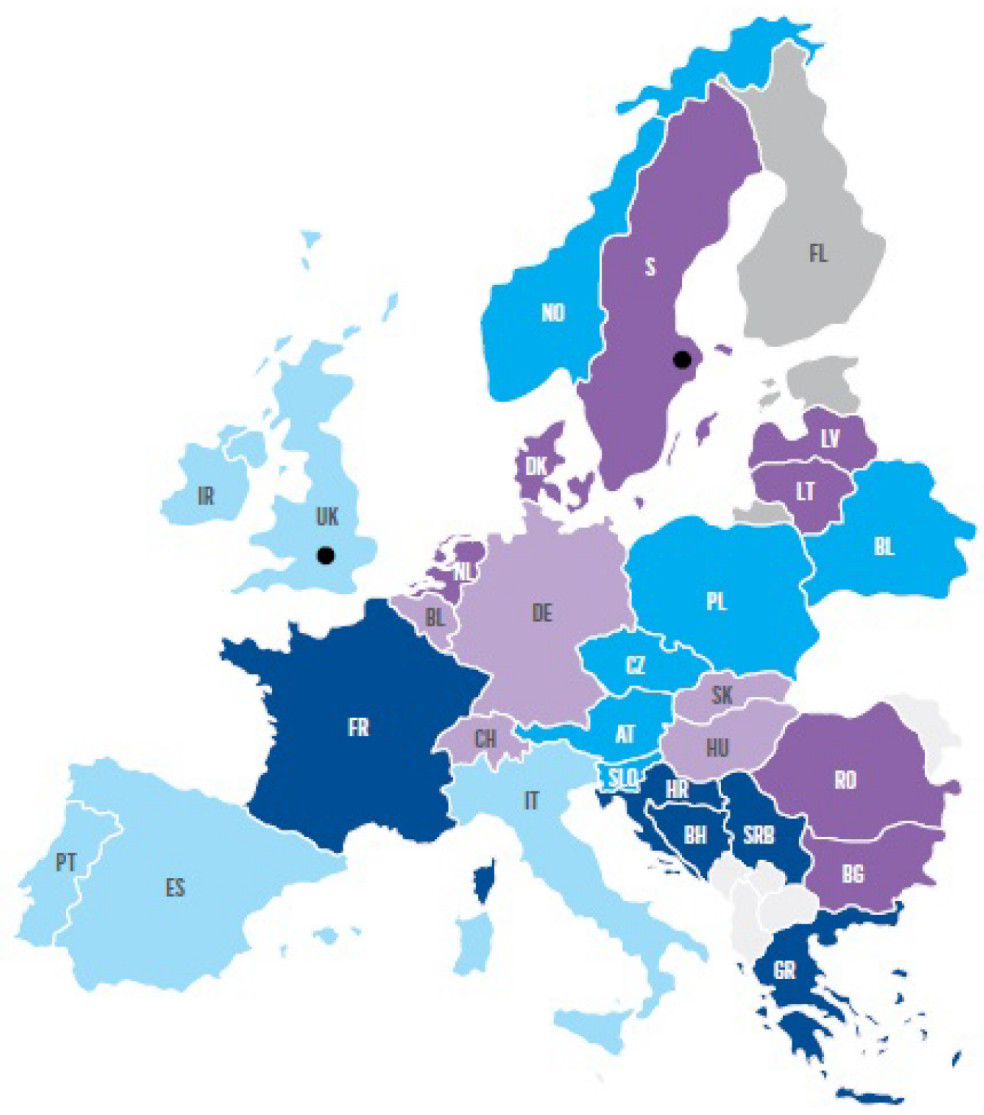

\section{According to distance; road barriers, DSRC}

According to distance; free flow; DSRC

According to distance; free flow; road barriers, DSRC

According to the time limit (vignette); free flow; vignette / e-vignette supported by ALPR

According to distance; free flow; GNSS

There is no charge

- $\quad$ ALPR (large cities)

Figure 2 - Toll payment in Europe for the heavy vehicles category [1] 
From the previous two figures it can be concluded that different toll collection systems are applied in different European countries, not only at the state level, but also for different categories of vehicles. Some countries have the same form of toll collection for all categories of vehicles, such as Portugal, Spain, France, Ireland, UK, Norway, Finland, Romania, Bulgaria, Italy, Croatia, Bosnia and Herzegovina and Greece. Other countries have developed two different toll systems with the aim of achieving higher throughput and better traffic control.

\section{Modern electronic toll collection system in Croatia from 2022}

One of the modern forms of electronic toll collection that allows minimal delay during the payment process is the ANPR ${ }^{5}$ system. The ANPR system is a method of mass monitoring the traffic via optical character recognition of an image which is read from a car's license plate.

The history of ANPR is significantly longer than most people think. Since ANPR technology has found its application in modern times, many would think it is a new discovery. ANPR dates back to 1976, when it was designed within the Police Scientific Development Branch, the first systems were put in use in 1979. In 1981, the ANPR was used for the first time to discover a perpetrator of a crime; the thief was found with a stolen car [6].

In 1993, the ANPR system was implemented in London as part of the Ring of Steel surveillance network using cameras, aimed at preventing terrorist bombings in the financial district. In 1997, this system was upgraded so that data collected across the UK was centralized, i.e. it was no longer available only to local police stations but to any police station in the country [6].

In 2006, the ANPR system was, for the first time used for a purpose other than monitoring vehicles in traffic. It was used to monitor vehicles in the parking lot, where the system records all cars in the parking lot and stores the exact time of entry and provides the parking controller with information on which vehicle did not pay for parking or stayed there too long [6].

Since 2009, ANPR in the UK is gaining another dimension; it is also being used to detect untaxed vehicles on the roads. In the first few hours of work in London, 27 such vehicles were recorded [6]!

Since 2013, the ANPR system has been used to monitor public transport in order to give city councils a better insight into traffic movements so they can make the best possible decisions in the development of road transport in order to relieve it [6].

Automatic Number Plate Recognition; also ALPR - Automatic Licence Plate Recognition 


\subsection{ANPR system operation technology}

As mentioned, ANPR represents an internationally recognized methodology of vehicle identification based on optical character recognition of images which are made by reading the car's registration plates [7]. In Figure 3 typical ANPR process is shown.

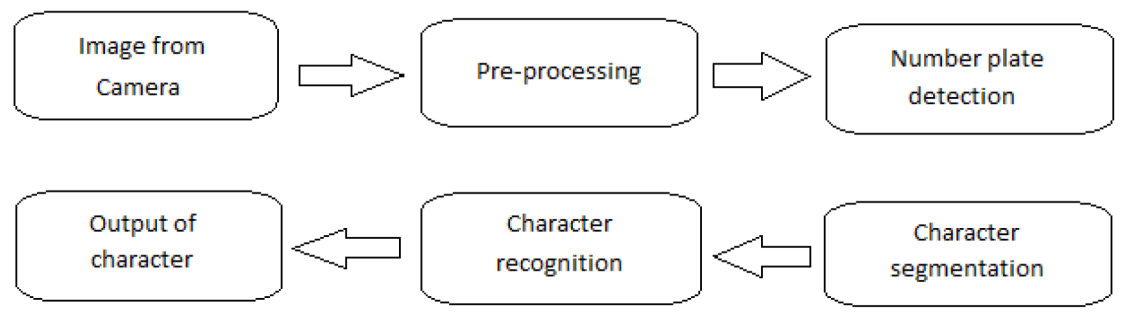

Figure 3 - Typical ANPR process [7]

ANPR system is based on the use of a camera that captures vehicle number plate images and then sends that data to the tool that allows pixels to be translated into numerical readable characters. Typical ANPR process can be divided into four main parts: image acquisition, licence plate detection, characters segmentation, and character recognition. Image of the vehicle is captured by the camera and it should be taken in a way that it contains rear (front) view of the vehicle so that it can read characters on the number plate. Usually it is captured in a RGB colour model [7]. After converting the colour image into a grey scale image, procedures are used to enhance the contrast in order to emphasize the displayed objects. The improvement of the image contrast is performed due to the inability to influence the negative scenarios that can occur during extracting the image from the vehicle, such as weak or inconsistent lighting, dirty or damaged license plates, etc. Along with the contrast enhancement, median filter, as a nonlinear digital filtering technique, is used to remove the noise from the image and to reduce the impact of damaged and dirty licence plates. Using the median filter does not cause blurring of the edges which makes this method especially effective for removing noise. Some systems use a median filter only after determining the position of the licence plate and its extraction. [8] In Figure 3 it is shown how a plate gets captured and how the plate's numbers axes are aligned so that system can process the data.

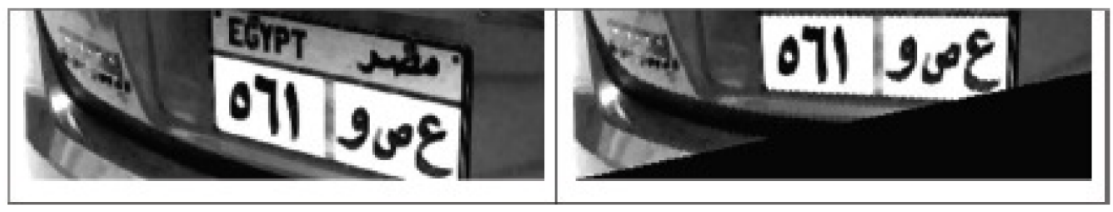

Figure 4 - Detecting the licence plate [9] 
Detecting the number plate can be affected by different factors, such as optical system, distortion, system noise, lack of exposure or excessive relative motion of camera or vehicle, etc. [7]The processing begins with the closure operation where dilation is first applied and then followed by erosion. In this way, all the white fields, smaller than a structural element which appears during binarisation, are filled. They appear mostly at the edges and can cause the appearance of several candidates for the registration plate or completely disable the detection and isolation. After the closing operation, an opening operation is conducted in which erosion is applied first, followed by the dilation operation. It removes the unwanted parts of the image that are smaller than the structural element. The opening is used to remove noise from the image and separate weak related objects. Opening and closing operations result in an image without noise with clearly defined edges and separated objects that represent potential candidates for the licence plate [8]. When number plate is detected, the image gets resized and converted from the coloured image into a grey scale image [7]. In Figure 5 it is shown how the number plate is localized and then turned from a coloured image into grey scale.

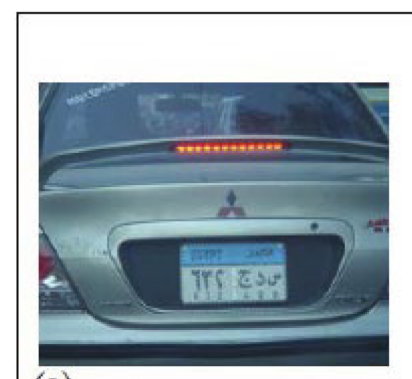

(a)

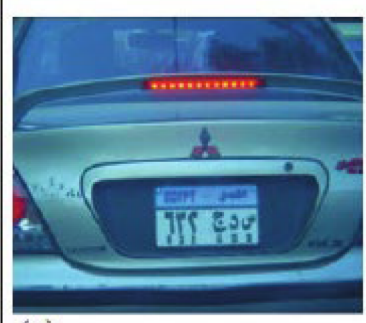

(c)

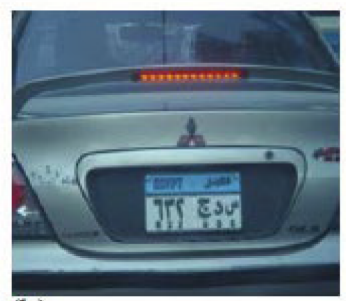

(b)



(d)

Figure 5 - (a) original image (b) after applying minimum filter (note that the diagonal strips passing through characters and edges of plate disappeared, and the characters became bold; this is important in order to have many strong ends around the characters) (c) after increasing saturation) (d) after converting to grey scale [9] 
The next stage is character segmentation which basically partitions images of lines or words into individual characters which can then be recognized in the last stage of ANPR process, character recognition. In Figure 6 character recognition flow is shown.

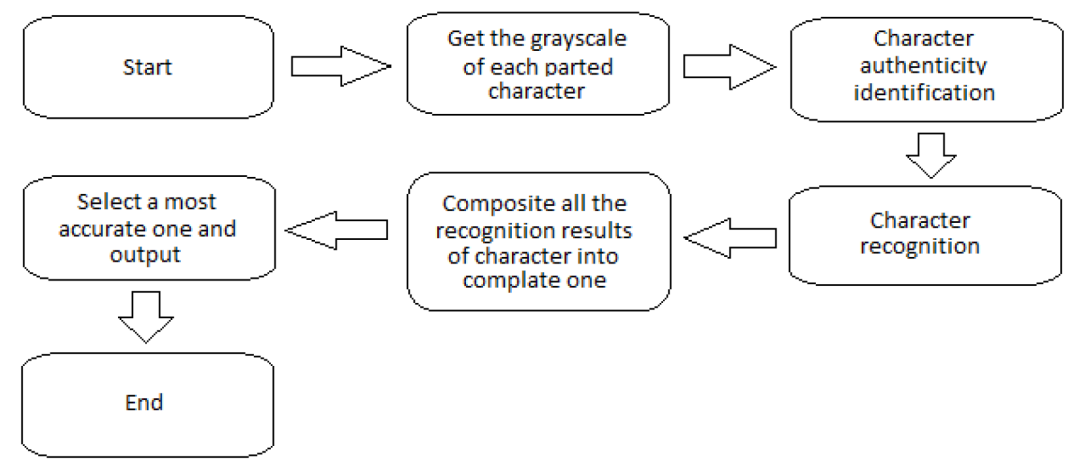

Figure 6-Character recognition flow chart [10]

A horizontal screening determines the borders between the characters upon which the segments of the licence plate containing the character that needs to be recognized are extracted. Each segment of the licence plate, which is the result of separation, other than alphabetical or numerical marks, contains redundant space and other adverse components. Adjacent pixels are grouped into several major parts, and only one of these parts represents a suitable sign. The aim is to divide a segment into parts, and to recognize only one, the one that truly represents the required sign. Similar to the procedure for the licence plate location and separation, undesirable elements are removed on the basis of certain criteria such as the ratio of the width and height, and the relations of black and white pixels [8].

Template matching is one of the most common classification methods in the last stage of an ANPR system. Individual image pixels are used as features. Classification is based on comparison of an input character image with a set of templates from each character class. To summarize the ANPR system: a camera takes a picture of the vehicle containing the number plate, then isolates the plate, and adjusts the brightness and contrast and segments it into characters. Pattern of each character is then analysed to convert the picture into text [7].

The great advantage of video systems used for automatic license plate recognition lies primarily in the fact that they do not require the installation of any of the components directly to the pavement, which is why the system is able to detect traffic in a completely unobtrusive way. The cameras are mounted on poles or structures above or along the pavement, and in order for the video system to be able to process the received images, it is necessary to enter known data, such as the distance between the lines or the height of the camera above the pavement. However, in order for this to be 
possible, the technological basis of the ANPR system must be met. ANPR has two basic technological prerequisites that it must meet in order to function successfully: quality ANPR software with algorithms which are used to recognize the tile and quality technology to obtain a photo of the tile (camera and lighting). There are seven basic algorithms that the software requires to successfully complete the license plate identification process [11]:

1. plate location - finding and isolating a plate in a photograph,

2. plate orientation and dimensions - compensates for the curvature of the plate in the picture and the dimensions to the required size,

3. normalization - adjusts the brightness and contrast of the image,

4. segmentation of alphanumeric characters in the photo - finds individual characters on the plate,

5. optical character recognition,

6. syntactic-geometric analysis - checks individual alphanumeric characters and their position and compares them with the prescribed specifications of license plates unique to each country,

7. adjusting the average (medium) recognized value across multiple fields / images to obtain a convincing and reliable result - only one photograph can give an inaccurate result (it may, for example, contain light reflection, be partially obscured or otherwise compromised).

From previous statements, a conclusion can be made that in the work of the ANPR system, many things can go wrong. It is wrong to assume that all ANPR systems can be used in the same way or that they can produce the same results. In ideal conditions, with good lighting and the latest technology, the accuracy of reading data is $90-94 \%$, while for older systems the statistics of accurate reading is much lower, between 60 and $80 \%$ [12] The technology is very complex, which is why it did not pass into wider use as soon as it was designed, although it was immediately recognized that this method, as a new way of controlling traffic, would greatly facilitate it. Although technology has advanced in many ways since the system was designed - from cameras that are better and give better images to software that reads, processes and converts image data into text based information, there are still a number of difficulties in operating this system.

Some of the most common problems are [11]:

$\diamond$ low image resolution, usually because the tile is too far away, but often because of a poor camera,

$\diamond$ blurred images, due to high vehicle speeds,

$\diamond$ poor lighting and low contrast due to excessive light, shadow, or reflection exposure,

$\diamond$ the readings on the front and rear license plates are different due to a trailer, a camper etc.,

$\diamond$ lack of cooperation between countries - two vehicles from different countries have the same label, 
$\diamond$ a foreign object obscures a part of the license plate - most often dirt or a towing hook.

Considering that ANPR has been finding its wider application in the last two decades, it is impossible to deny the advantages of this technology. In order to use it properly, the application of ANPR technology has to be accompanied with quality planning, implementation, training and proper technology management. As it is the case with some other tools and technologies, ANPR must be well managed. Given the fact that it enables traffic monitoring, and thus directly creates the possibility of monitoring car users and gaining knowledge about their lifestyle and movement, this directly affects the users' privacy status. Institutions using this technology must clearly define their strategic goals for the use of this technology and adhere to it in accordance with existing laws. Therefore, it is first and foremost necessary for all people who operate such systems to undergo quality and comprehensive training, to ensure that the technology is used correctly - and to collect the correct data, but also to preserve the privacy of car users who this system monitors. Special attention should therefore be paid, to ensure the quality of the data and to the security of the system that processes the data, so that the use of the system complies with all laws, regulations and that the privacy of collected data is preserved [14].

\subsection{Changes in the electronic toll collection system as a consequence of the introduction of the ANPR system in Croatia}

The existing (closed) toll collection system in the Republic of Croatia has basically not changed since the construction of the first sections of motorways almost 50 years ago. A technical innovation and an intermediate step in contactless toll collection was the introduction of the ETC (electronic toll collection) in 2006, which is currently used by about $40 \%$ of motorway users in Croatia. With the persistent increase in traffic, but also due to the high seasonality of motorway use (tourist season), various models have been considered in recent years to replace the existing, basically obsolete and nonfunctional system with a more modern model, which would also ensure interoperability with other systems in the European Union. By the end of 2021, the Republic of Croatia plans to introduce an automated billing system that will be interoperable with the system of other EETS member states (European Electronic Tolling System). The selected resolution should take into account the specifics of the Croatian motorway infrastructure such as traffic frequency (high seasonality), user habits and the cost of switching to new technology, but also interoperability with domestic concessionaires. In accordance with the decision of the Government of the Republic of Croatia on accepting business and financial restructuring of the road sector, it was decided that the Republic of Croatia would maintain the current toll collection system, with the introduction of one of the electronic (contactless) toll collection systems. As part of the project of modernization and restructuring of the road sector (MARS) in 2018, an 
international bidding was launched for the selection of consultants who will present the optimal solution of the electronic toll collection model for the Republic of Croatia as part of a comprehensive project as well as the analysis of the existing models. The Spanish consulting company IDOM was selected in the tender, their experts prepared a study of the new electronic payment system [1].

When the analysis of all existing electronic systems was started, in order to reach an optimal solution with regard to the existing conditions of Croatian motorways, five key goals were set. The goals are defined as follows [1]:

1. a technological system that is not locked by the ownership decision of the manufacturer or service provider,

2. interoperability between different concessions and other European charging systems,

3. decrease in traffic jams,

4. scalability (adaptability) over road networks where possible,

5. optimization of operating costs,

6. increase in safety (return of traffic to motorways from local roads), and reduction of pollution through the free flow system (without stopping at toll booths).

Taking into account all of the mentioned objectives, it was decided that the new system will be based on a combination of two modern and proven technologies: billing via an upgraded version of the in-vehicle ETC device (DSRC) and the automatic license plate reading system (ALPR), which are among the proven technologies used in the EU. Thus, the use of ETC will be mandatory for heavy vehicles, while light vehicle users will have a choice.

The contractors of the study did not ignore the high seasonality and the fact that almost $85 \%$ of all tourists in the Republic of Croatia come to the country by road, so a solution was offered for users who do not need to purchase ETC, or for people who are not frequent motorway users.

At the same time, the system will be interoperable with the existing electronic payment systems in the EU, and after the initial implementation on the shares of HAC and ARZ, it is expected to be introduced on the shares of other concessionaires in the Republic of Croatia.

Given the technological challenges, Croatia will not be able to apply satellite tracking technology (GNSS), which requires significantly more investment, especially for the user, and this technology has not yet been introduced in any European country for the first group of vehicles due to doubts about user privacy issues [15].

This type of a toll system, selected for the application of motorway toll collection in Croatia from 2022, enables, above all, a significantly higher flow of cars per hour.

In Table 1 the statistics of car flow per hour is shown. 
Table 1 - Car flow per hour via different toll payment systems [1]

\begin{tabular}{|l|l|}
\hline Payment model & Vehicles per hour \\
\hline Manual collection (cashiers) & 200 \\
\hline Billing machines & 350 \\
\hline ETC & 600 \\
\hline Fast ETC & 1.000 \\
\hline Free passage (DSRC \& ALPR) & 3.000 \\
\hline
\end{tabular}

In Table 2 SWOT analysis of modern electronic toll collection system in Croatia is presented. The SWOT analysis table clearly shows the strengths, threats, weaknesses and opportunities of the new system that will mean a revolution for road traffic in Croatia.

Table 2 - SWOT analysis of modern electronic toll collection system in Croatia [1]

\begin{tabular}{|c|c|}
\hline STRENGHTS & THREATS \\
\hline $\begin{array}{l}\text { - the current crowds at toll stations } \\
\text { will disappear } \\
\text { - } \text { synergy with existing infrastructure } \\
\text { - } \text { the user is accustomed to paying tolls } \\
\text { ropean directives } \\
\text { - non-discriminatory solution for } \\
\text { senior users for personal vehicles } \\
\text { (tourists) } \\
\text { - same technological solution as the } \\
\text { one currently used (ETC - DSRC), } \\
\text { compatibility with existing private } \\
\text { concessions } \\
\text { - The possibility of cash embezzle- } \\
\text { ment will disappear } \\
\text { advanced solution that can deliver } \\
\text { more than five technology suppliers } \\
\text { with references from similar projects } \\
\text { (competitiveness) }\end{array}$ & $\begin{array}{l}\text { - the need to change the legal frame- } \\
\text { work } \\
\text { - user resistance } \\
\text { - lower ETC penetration will increase } \\
\text { OPEX } \\
\text { - possible crowds at border cross- } \\
\text { ings to purchase ETC or register for } \\
\text { ANPR }\end{array}$ \\
\hline
\end{tabular}




\begin{tabular}{|l|l|}
\hline WEAKNESES & OPPORTUNITIES \\
\hline$\bullet$ investment cost & $\begin{array}{l}\text { - the need to renovate the existing toll } \\
\text { collection system }\end{array}$ \\
& $\begin{array}{l}\text { - } \text { organizational restructuring } \\
\text { - }\end{array}$ \\
& solutions implemented in other coun- \\
tries as a source of acquired experi- \\
ence and good practice \\
- international bodies with funds for \\
project preparation and development \\
improving customer service
\end{tabular}

It is estimated that the new system, without the need for major upgrades, will function effectively for at least 15 years, while on a monthly basis savings could amount to about HRK 13 million compared to the current system characterized by high costs of toll booths, cashiers, cash transport and the like. The planned savings will reflect on the further reduction of the road debt, on which the state already saves around EUR 50 million a year in interest after refinancing. The new billing system will enable simpler and faster price formation, for example higher prices at the time of the highest congestion and lower prices (tariffs) in periods of less dense traffic. As before, frequent users will be able to get discounts via ETC devices. Implementation of the system, which includes the purchase of new technology, construction of a portal for automatic toll collection, adaptation of existing tracks and dismantling of toll stations, will cost up to HRK 570 million with savings on operating costs of the new toll system which will reach the investment amount in 7 years. Work on the implementation of the system began in 2020, and is it planned to be put into practice in 2022, with a transitional period in which both systems will operate simultaneously to allow users to easily adapt from a closed to an open billing system. An amendment to the legislative framework has also been announced, which will quickly and effectively sanction potential criminal perpetrators with high fines [15].

\section{Conclusion}

Since the construction of motorways in Croatia about 50 years ago, there was no change in the method of toll collection until 2006, when charging via ETC devices was introduced. Croatia is a tourist country with a substantial amount of tourists during the summer season $85 \%$ of which arrive by road. Every year, Croatia records an increasing number of tourists, which every year means more and more crowds at toll stations. The old toll collection system proved to be unsustainable in many ways, due 
to congestion, high costs, etc., which is why an initiative was launched to restructure traffic and select a new (electronic) toll collection system. The combination of charging via ETC devices and ANPR technology was proven by studies to be optimal for toll collection in Croatia starting from 2022. The same methods are used by many other (highly developed) European countries. The threats and disadvantages of the new toll collection system are few in comparison to the advantages and opportunities, which is why the introduction of a modern electronic toll collection system will truly represent a real revolution in the road transport of the Republic of Croatia.

\section{Literature}

1. Ministarstvo mora, prometa i infrastrukture (2019) Novi sustav elektroničke naplate cestarine na autocestama u Republici Hrvatskoj. Zagreb: Ministarstvo mora, prometa i infrastrukture.

2. Hrvatske autoceste (2020) Korištenje autoceste $i$ naplata cestarine. Available at: https://www. hac.hr/hr/cestarina [Acessed $22^{\text {nd }}$ May 2020].

3. Hrvatske autoceste (2020) ETC. Available at: https://hac.hr/hr/cestarina/ETC? etc=1 [Acessed $22^{\text {nd }}$ May 2020].

4. Drlja, M. (2016) Elektronički načini plaćanja cestarine u RH. Završni rad. Šibenik: Veleučilište u Šibeniku.

5. Hrvatske autoceste (2020) Skupine vozila. Available at: https://hac.hr/hr/cestarina/cjenik [Acessed $22^{\text {nd }}$ May 2020].

6. ANPR International (2020) History. Available at: http://www.anpr-international.com/history-ofanpr/ [Acessed 24 ${ }^{\text {th }}$ May 2020].

7. Shibwabo, B., Mutua Raphael, K. (2017) Number Plate Recognition System for Car Park Management. International Journal of Computer Applications, 175(7), pp 36-42.

8. Ćelić, J. i Kezić, D. (2012). Sustav za automatsko nadziranje cestovnog prometa. Pomorstvo, 26(2), pp 397-411.

9. Badr, A., Abdelwahab, M. M., Thabet, A. M., Abdelsadek, A. M. (2011) Automatic Number Plate Recognition System. Annals of the University of Craiova, Mathematich and Computer Science Series. 38(1), pp 62-71.

10. Hikvision (2017) Automatic Number Plate Recognition Technology: A universal and efficient algorithm for global ANPR application. Hanghzou: Hikvision.

11. Tomić, A. (2016) Automatsko prepoznavanje registarskih pločica. Krapina: Veleučilište Hrvatsko zagorje Krapina.

12. Haines, A. (2009) The role of automatic number plate recognition surveillance within policing and public reassurance. Huddersfield: University of Huddersfield.

13. Roberts, D. J., Casanova, M. (2012) Automated License Plate Recognition (ALPR) Use by Law Enforcement: Policy and Operational Guide, Summary. Alexandria: IACP Techology Center.

14. Blythe, P. T., Knight, P., Walker, J. (2001) The Technical and Operational Feasibility of Automatic Number-Plate Recognition as the Primary Means for Road User Charging. Journal of Navigation, 54(3), pp 345-353.

15. Hrvatske autoceste (2019) Uvodi se suvremeni sustav elektroničke naplate cestarine sa slobodnim prolaskom vozila. Available at: https://www.hac.hr/hr/odnosi-s-javnoscu/novosti/od-2022-g-bezzaustavljanja-na-naplatnim-postajama-autocesta [Acessed $10^{\text {th }}$ June 2020]. 